Brazilian Journal of political Economy, vol. 30, n 2 (118), pp. 189-200, April-June/2010

\title{
Are we all Keynesians?
}

\section{MARC LAVOIE*}

This essay asks whether we are all becoming Keynesians again. It offers some thoughts about the impact of the financial crisis on macroeconomic theory and Keynesian theory, and on post-Keynesian theory in particular. It is argued that the crisis does have obvious effects on how Keynesianism is being perceived by decision makers, and that some effects are also observed on academia. However, there are forces within the economics profession and the population at large which are resistant to this second coming of the Keynesian revolution.

Keywords: keynesianism; financial crisis; macroeconomics; counter revolution.

JEL classification: B4; B5.

The subprime financial crisis, which started in mid-August 2007, but many signs of which already appeared on interbank markets during the first months of 2007, has no doubt rekindled interest in Keynes and Keynesian economics. Several of my heterodox friends and colleagues have been asked to write or rewrite books on Keynes and his theories, as if these theories had been long forgotten. The three books of Hyman Minsky have been reedited and could even be found on bookstands in airports. There is clearly a revival of Keynesian economics, certainly among journalists and the public, perhaps even in the academic world.

This essay asks whether we are all becoming Keynesians again. It offers some thoughts about the impact of the financial crisis on macroeconomic theory and Keynesian theory, and on post-Keynesian theory in particular. I start by reminding the various sorts of Keynesians there are out there, and by providing a useful defini-

\footnotetext{
"Department of Economics, University of Ottawa. E-mail marc.lavoie@uottawa.ca. This paper is part of a presentation that was made at the second Encontro Internacional de Associação Keynesiana Brasileiro, which was held in Porto Alegre in September 2009. I am much grateful to the organizers for having invited me to participate in one of their plenary sessions and I would like to thank in particular Fernando Ferrari Filho for his kind and generous hospitality. I am also thankful for the encouraging comments of Jan Kregel and Gary Dymski during the conference. Submitted: September 2009; Approved: November 2009.
} 
tion of dissent. The next section discusses whether there is a second pragmatic Keynesian revolution going on, while the third section discusses whether there is such a revolution at the theoretical level. The fourth section notes that there are highly conflicting messages out there, and that there is a substantial amount of resistance to the Keynesian message among the (American) population. The concluding section draws some likely scenarios for orthodox and heterodox Keynesians.

\section{DEFINING KEYNESIAN ECONOMICS}

If we are to assess the impact of the financial crisis on Keynesian theory, we first need to define what Keynesian economics is. This of course is not an easy task. There are many brands of Keynesian economics, both orthodox and heterodox ones.

The orthodox ones are usually called New Keynesians, and they used to be divided for convenience into three kinds, depending on their focus: nominal price rigidities, real rigidities, and coordination failures. New Keynesians of the third kind are now called Post Walrasians by David Colander (1996).These distinctions may only be partially relevant today as several New Keynesians seem to be enamoured with the new classical dynamic stochastic general equilibrium model (DSGE), amended with rigidities, thus arriving at the New consensus model, or the so-called New Neoclassical synthesis, where money, if any is needed, is endogenous and central banks set interest rates, but where decisions are taken by forward-looking agents who maximize inter-temporal utility into the nearly infinite future. Other New Keynesians, of the Stiglitz and Greenwald (2003) variety, hang on to monetary economics, on the basis of information deficiencies, and focus on credit markets and the possibility of loan defaults, thus showing some resemblance with heterodox Keynesians concerned with financial fragility.

The heterodox Keynesians themselves can be divided into three strands: the Fundamentalist Keynesians, who track the writings of Keynes in search of uncertainty, liquidity and Marshallian foundations; the Kaleckians/Kaldorians, who enjoy formalization, and revisit some of the insights of Kalecki and Kaldor and their class concerns; and finally the neo-Ricardian Keynesians, more inspired by the writings of Sraffa and those of some classical economists, but whose ideas on monetary economics and growth do resemble now those put forth by Kaleckians. I will say no more as I have explained elsewhere how I see the links between these various strands of heterodox Keynesianism (Lavoie, 1992).

This being said, what defines Keynesianism? Asking the question and providing some answers obviously shows further that there is a wide variety of Keynesianism out there. A belief in any of the statements put below would probably qualify his or her holder to be part of some of brand of Keynesianism.

The existence of involuntary unemployment

The principle of effective demand and the paradox of thrift

The existence of an independent investment function 
That capitalism is the best system but that it needs to be tamed

That markets, especially financial markets, are inherently unstable

The need for fiscal counter-cyclical policies

The need for capital movement impediments, managed exchange rates

The role of animal spirits and fundamental uncertainty

The non-neutrality of money, the significance of liquidity

The dangers of wage and price deflation

The existence of path dependence, multiple equilibria, and hysteresis

The existence of imperfections that thwart price adjustments

At this stage, it may be highly useful to make use of the distinction provided by Roger Backhouse (2004). He argues that economists can be divided into two broad groups: the mainstream and the dissenters. But the dissenters themselves can be subdivided into two additional groups: the orthodox dissenters and the heterodox dissenters. Those three groups are represented in Figure 1, with the heterodox dissenters in black on the left, the mainstream in dark grey on the right, and the orthodox dissenters in light grey or white, in between the other two groups.

Figure 1: Orthodoxy, Dissent, and Heterodoxy

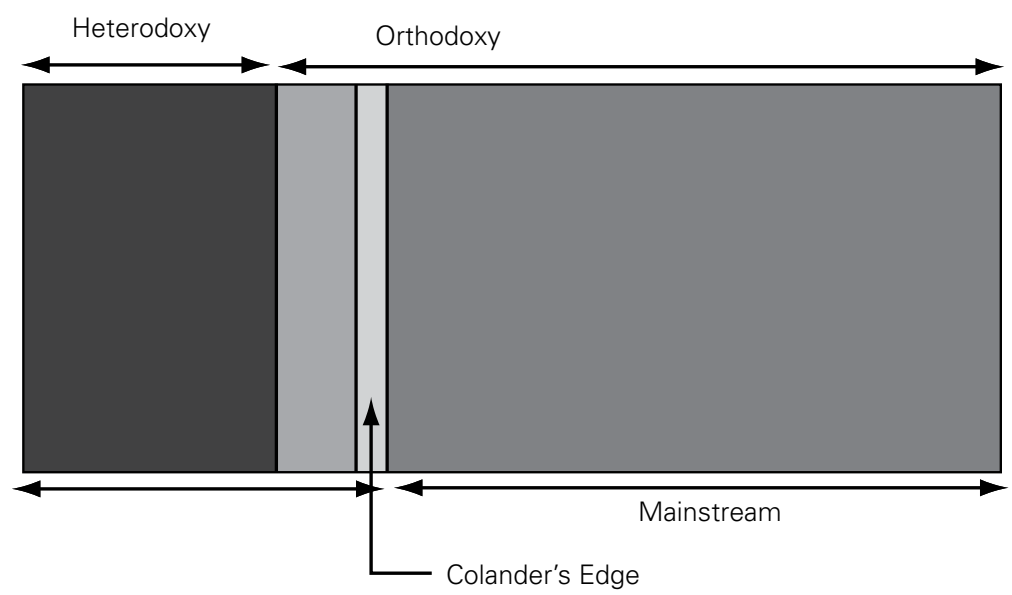

Heterodox dissenters are unlikely to become part of the mainstream, and their position in the pecking order is likely to remain precarious, despite the fallouts of the subprime financial crisis. By contrast, orthodox dissenters may turn into heterodox dissenters or may become part of the mainstream, either from their own volition or because the bulk of the profession moved towards the propositions of these dissenters. Backhouse offers some examples of orthodox dissenters, such as the French disequilibrium school in the late 1970s, with Malinvaud and Bénassy. Keynes himself, with the publication of the General Theory in 1936, may be perceived as an orthodox dissenter. Milton Friedman was certainly a dissenter in the 1950s, but then his views became mainstream in the late 1960s. Similarly, the New consensus model, based as it were on a central bank reaction function involving the rate of interest, 
instead of the money supply stock, was certainly considered as orthodox dissent in its beginning, but as we pointed out earlier, it is now the bread and butter of central bank researchers. Other examples of orthodox dissent may include the work of authors as diverse as Robert Shiller, Richard Thaler, Colin Camerer, Harvey Liebenstein, Dan Rodrick, Herbert Simon, Ronald Coase, Wassily Leontief, Amartya Sen, George Akerlof, Paul Krugman, Joseph Stiglitz, Oliver Williamson, or Bill Vickrey. Indeed many of these authors have explicitly stated that they certainly did not want to rock the mainstream boat. Thaler for instance, is cited as saying that he did not want "to lay waste to the entire mathematical, hard science apparatus that economists had built after World War II" (Fox, 2009, p. 187).

Obviously getting a Nobel prize seems to be helpful for a dissenter to be heard. But it may also be that orthodox dissenters are the "cutting edge" of orthodox economics, the really serious and innovative people arising out of the mainstream (they are represented by the small area in white in Figure 1). For Colander and his co-authors $(2004$, p. 492), the cutting edge is that part of dissent "that is taken seriously by the elite of the profession". If this is true, then it is likely that the financial crisis will make Keynesian orthodox dissenters - mainly New Keynesians of the third kind - more likely to be taken seriously by their mainstream majority colleagues than it will ever be the case for Keynesian heterodox dissenters.

\section{A SECOND PRAGMATIC KEYNESIAN REVOLUTION?}

The question as set up in the title of this essay would seem to presuppose that at least some of the statements defining Keynesianism, as outlined in the previous section, had been abandoned by many, perhaps even most, economists. It implies that Keynesianism is having a resurgence. But was Keynesianism ever set aside? It is hard to give a clear yes or no answer. Clearly, in academia, Keynesianism was nearly a dirty word as economists like Robert Lucas spoke of the "death of Keynesian economics" or are reported to say that "at research seminars, people don't take Keynesian theorizing seriously anymore; the audience starts to whisper and giggle to one another" (Mankiw, 2006, p. 34). After its eclipse in the late 1970s with the generalization of the Friedmanian expectations-augmented Phillips curve, rational expectations and compulsory micro-foundations, Keynesianism did make a comeback and became more respectable when New Keynesians turned the tables on New classical authors and provided infinite possibilities for doctoral dissertations by providing micro-foundations for all kinds of imperfections or self-fulfilling prophecies.

Things may be entirely different at the policy level, at least in the rich industrialized countries. Gregory Mankiw (2006, p. 42) in that regard claims that "the sad truth is that the macroeconomic research of the past three decades had had only minor impact on the practical analysis of monetary and fiscal policy". $\mathrm{He}$ believes that the New consensus model, based on particularly outrageous assumptions, has had no impact on macroeconomic engineering. However, Michael Woodford, who has written the Bible of this New consensus model, as one would expect 
begs to differ. He argues that "it is now widely agreed that macroeconomic analysis should employ models with coherent intertemporal general-equilibrium foundations" (Woodford, 2009, p. 268), and he adds that the models being used either at Treasuries or at central banks are DGSE models that reflect the New consensus methodology and hence that there is "no disconnect between the science of macroeconomics and the engineering side" (ibid., p. 277). As some quotes that we will provide later show, there is no doubt that the New consensus model, which at best contains the sticky price variety of Keynesianism, is the key inspiration in central bank modeling.

But does this mean that Keynesianism was dead? It was certainly surviving in this weakened form. Fifteen years ago, James Galbraith (1994-95, p. 257), who has worked around Congress and the Capitol Hill for a long time, was very strongly arguing that Keynesianism was well alive among policy makers: "Keynesianism of a crude sort remains the dominant policy creed in the United States today. And it is the anti-Keynesian economists, the high priests of rational expectations, Ricardian equivalence, and other mumbo-jumbo, who have failed to connect with the common sense of ordinary people. Anyone who has tried to explain to undergraduates why virtually all unemployment must be voluntary knows how hard this is". While it is certainly true that the ordinary persons in the street can't fathom Barro's argument that they should reduce their current consumption expenditures because current public deficits will induce higher future tax rates, these same persons can easily be persuaded that public deficits are bad under all but the worse circumstances because the government should behave like a household and tighten its belt when times are rough.

Whether governments were recently pursuing Keynesian policies, or whether they ever did pursue Keynesian policies in the past, meaning the pursuit of strong counter-cyclical policies along the lines of Abba Lerner's functional finance, or whether their policies came closer to the principles of sound finance, is now a moot point. We know that when a serious economic crisis did hit the major industrialized countries, as it became clear in the autumn of 2008 , there was a complete turnabout of the major actors. The IMF, which had at all times relied on the policies advocated by the Washington consensus and imposed harsh deflationary policies to the countries that were bad-lucked enough to fall prey to a financial or currency crisis, recanted from its previous pronouncements. During the recent subprime financial crisis, the IMF very strongly advocated low interest rates instead of high interest rates to regain confidence, and it was at the vanguard to promote government stimulus packages with large public deficits.

G20 leaders acted along the lines recommended by the IMF. At the London April 2009 summit they announced that their governments had undertaken concerted fiscal expansion, to save jobs and stimulate production and sales. They pledged to make sweeping reforms to reinforce financial regulation and oversight, a pledge that was repeated at the Pittsburgh September 2009 G20 summit, thus announcing that the era of bank secrecy and unfettered financial markets was over, giving way to supervised capitalism. It is true that these announcements were si- 
multaneously accompanied by pledges for exit strategies that would involve "long-term fiscal sustainability" and "fiscal responsibility", but at least there was a promise and an awareness "to avoid any premature withdrawal of stimulus", as any good Keynesian policy would suggest.

But the most surprising turnaround is no doubt that of the Financial Times, the website of which now claims in a sidebar that "the credit crunch has destroyed faith in the free market ideology". This and the enormous stimulus packages put forth by many governments in industrialized countries and in countries such as China certainly show that the subprime financial crisis has brought about a second Keynesian revolution, even if it is only a pragmatic one.

\section{A SECOND ACADEMIC KEYNESIAN REVOLUTION?}

The Great Depression of the 1930s no doubt had a lasting effect on economists in academia. Will the subprime crisis have a similar effect? Perhaps it is too early to say. The subprime financial crisis has been in full throttle only since September 2008 , so economists in their ivory towers have had no time yet to fully realize the amplitude of the crisis and its possible negative long-run impact, as well as its implication for the core assumptions of macroeconomic theory. Indeed, while Geoffrey Hodgson (2009, p. 1206) believes that the crisis has led to a change in opinion among world politicians, for instance with Gordon Brown, the Prime Minister of Britain, affirming that the "Washington consensus is out", or with his Chancellor of the Exchequer, Alistair Darling saying that Keynes is coming back into vogue, Hodgson despairs of his academic colleagues, claiming that "as yet there are no strong shifts of opinion or practice among academic leaders of our profession. We search in vain for similar conversions or recantations". It would be business as usual among academic economists.

There are however some recantations. Perhaps the most surprising recantation is that of Richard Posner, a judge and a senior lecturer at the University of Chicago School of Law. Posner was a stern defender of free markets and Friedman's ideology. In his book titled The Failure of Capitalism, Posner (2009a) argues that deregulation went too far and that financial markets need to be heavily regulated, because banking has an systemic significance that other industries do not have. In a follow-up article, provocatively titled How I became a Keynesian, Posner (2009b) goes further, arguing that "we have learned since September [2008] that the present generation of economists has not figured out how the economy works". Posner believes that Keynes's General Theory, despite its apparent antiquity, is the best guide to the crisis, because "Keynes wanted to be realistic about decision-making rather than explore how far an economist could get by assuming that people really do base their decisions on some approximation to cost-benefit analysis", a view which is presented to the general public in the latest book of Paul Davidson (2009). A very similar point, showing disarray at the obviously counterfactual assumptions 
about human behaviour entertained by mainstream economists, has also been made by Akerlof and Shiller (2009, p. 268) in their recent book:

"It is necessary to incorporate animal spirits into macroeconomic theory in order to know how the economy really works. In this respect the macroeconomics of the past thirty years has gone in the wrong direction. In their attempt to clean up macroeconomics and make it more scientific, the standard macroeconomists have imposed a research structure and discipline by focusing on how the economy would behave if people had only economic motives and they were also fully rational."

Less surprising probably are the critiques made by Willem Buiter to mainstream theory in general and the New consensus model in particular. Buiter, an LSE professor and a former member of the Monetary Policy Committee of the Bank of England, has been a harsh critique over the last few years of both the New consensus model and the fiscal theory of prices, two fashionable macroeconomic models, just as James Tobin, former co-author of his, was critical of New Classical and New Keynesian models when they started bursting into the scene in the 1970s and 1980s. In the following quote, Buiter (2009), like Akerlof and Shiller in the previous quote, questions the usefulness of new classical theory, real business cycle theory, and the New consensus model - all the fads of macroeconomics over the last thirty years. He provides an internal critique of these models which is as harsh as any critique can be.

"Indeed, the typical graduate macroeconomics and monetary economics training received at Anglo-American universities during the past 30 years or so, may have set back by decades serious investigations of aggregate economic behaviour and economic policy-relevant understanding. It was a privately and socially costly waste of time and other resources. Most mainstream macroeconomic theoretical innovations since the 1970s (the New Classical rational expectations revolution associated with such names as Robert E. Lucas Jr., Edward Prescott, Thomas Sargent, Robert Barro etc., and the New Keynesian theorizing of Michael Woodford and many others) have turned out to be self-referential, inward-looking distractions at best. Research tended to be motivated by the internal logic, intellectual sunk capital and esthetic puzzles of established research programmes rather than by a powerful desire to understand how the economy works - let alone how the economy works during times of stress and financial instability. [...]

In both the New Classical and New Keynesian approaches to monetary theory (and to aggregative macroeconomics in general), the strongest version of the efficient markets hypothesis (EMH) was maintained. This is the hypothesis that asset prices aggregate and fully reflect all relevant fundamental information, and thus provide the proper signals 
for resource allocation. Even during the seventies, eighties, nineties and before 2007, the manifest failure of the EMH in many key asset markets was obvious to virtually all those whose cognitive abilities had not been warped by a modern Anglo-American Ph.D. education. But most of the profession continued to swallow the EMH hook, line and sinker, although there were influential advocates of reason throughout, including James Tobin, Robert Shiller, George Akerlof, Hyman Minsky, Joseph Stiglitz and behaviourist approaches to finance."

But the last straw for Buiter has been the inability of central bankers to take any decision based on fashionable mainstream models, such as the DSGE New consensus models. In fact, while these models pertain to analyze monetary economies, they describe instead a world where money and financial markets are not needed and play no essential role. This feature, as recently recalled by Colin Rogers (2009), can be traced back to the Walrasian micro foundations of these state-of-the-art models. Buiter makes the same point, since Walrasian models assume a kind of centrally planned economy.

"Both the New Classical and New Keynesian complete markets macroeconomic theories not only did not allow questions about insolvency and illiquidity to be answered. They did not allow such questions to be asked. [...] Models of the economy that incorporate the EMH - and this includes the complete markets core of the New Classical and New Keynesian macroeconomics - are not models of decentralised market economies, but models of a centrally planned economy. [...] The Bank of England in 2007 faced the onset of the credit crunch with too much Robert Lucas, Michael Woodford and Robert Merton in its intellectual cupboard. A drastic but chaotic re-education took place and is continuing." (Buiter, 2009)

\section{MIXED SIGNALS}

Paul Krugman (2009) has also made quite a stir by ridiculing fresh-water macroeonomists - the New Classical authors from Chicago and Rochester - in his review of the evolution of macroeconomics, criticizing both their assumptions and their apparent lack of knowledge of elementary Keynesian economics, as the most famous New Classical authors reverted to what should have been well-known pre-Keynesian arguments to counter the justification of stimulus programmes. Despite throwing some barbs to his fellow New Keynesians, because they too easily embraced the efficient market hypothesis and rational expectations, Krugman seems to be confident that pragmatic economists will manage to put macroeconomics back on track, by appropriately taking into account, so it seems, behavioural eco- 
nomics and behavioural finance, as exemplified by the work of the likes of Akerlof and Shiller.

But as John King points out (2009, p. 6),"there is little evidence" in Akerlof's Nobel speech "of an emerging school of behavioural economics". My reading of the book of Akerlof and Shiller (2009) leads me to the same conclusion. When I listened to Shiller a few years back, I came under the impression that he was a closet post-Keynesian economist, who happened to be specialized in finance. But while Shiller and Akerlof clearly indicate that they believe economic agents act on the basis of animal spirits and confidence, as well as notions of fairness and envy, their book tells the usual stories based on money illusion, efficiency wage theory and loanable funds. It would seem that Krugman and others see potential, when so far, there is just a glimpse of hope.

In fact, the reaction of people like Krugman, Buiter or Charles Goodhart (2009) is rather revealing. They barely mention, when they do, the work of heterodox Keynesians, such as that of the post-Keynesians, or more precisely in the context of the present financial crisis, the work of Minskyans. Clearly, the hope is that through some miracle, salt-water macroeconomists (pragmatic economists) will manage to incorporate real-world concerns in the state-of-the-art mainstream macroeconomic models. But as Kaldor $(1966$, p. 310) remarked a long time ago, "it is the hallmark of the neo-classical economist to believe that, however severe the abstractions from which he is forced to start, he will 'win through' by the end of the day - bit by bit, if he only carries the analysis far enough, the scaffolding will be removed, leaving the basic structure intact. In fact these props are never removed", for otherwise the whole structure collapses. These comments certainly apply to the New consensus models, which are based on highly unrealistic assumptions, to which some realistic features, such as central bank interest rate reaction functions with endogenous money and sticky prices, get superposed.

Over the last twenty years, the accepted framework to do macroeconomics has become ever more stringent, as pointed out by several authors (Dutt, 2003), with the compulsory introduction of the forward-looking optimizing representative agent. This is confirmed by my personal experience as a co-writer of the Canadian version of the first-year textbook authored by Baumol and Blinder. It turned out to be much easier to convince the readers of the microeconomic part of the textbook to accept innovations and changes to the standard view; by contrast, we were harassed whenever we attempted to introduce heterodox ideas in the macroeconomic section. While there is a certain amount of tolerance when it comes to microeconomics, with the advent of experimental economics, behavioural economics, game theory and multi-agent modeling, macroeconomics seems to be too tightly linked to ideology and to high stakes - the future of unfettered and unregulated capitalism.

Indeed, while there is a strong revival of Keynesianism among politicians and their advisers, a very strong counter-revolution is also occurring against Keynesian economics. This is particularly evident in the United States, where both neo-Austrian and libertarian economists and right-wing citizens, appalled by the large fiscal 
deficits of the federal government, the quasi-nationalization of several financial institutions and the attempt to set up a comprehensive public health program, are balking at the idea that Keynesian macro policies and the welfare state could be back into fashion. These defenders of market faith, organized through blogs and television networks (FOX), claim that government intervention and bad regulation are the causes of the crisis, blaming newly-elected President Obama for the continuation of the crisis. For these anti-Keynesians, free-market capitalism is essentially stable and nearly perfect, as assumed also by New classical economists and believers in the efficient market hypothesis.

The crisis, according to authors such as Thomas Woods (2009) has been caused by a combination of three factors: US government policy, through the Community Reconstruction Act (CRA), has forced banks to grant subprime loan, notwithstanding the fact that the Act was voted in 1997; the Federal Reserve has set short-term rates at too low a level for too long during the 2002-2004 period; the Chinese have rigged the exchange rate system, and have flooded long-term US bond markets, also leading to overly low long-term bond interest rates. Briefly put, crises would never arise if government was small enough and if interest rates were always set at their natural levels. In their view, a view reasserted recently by more than 300 economists in a petition to President Obama (including John Cochrane, Eugene Fama, Richard Muth, William Poole, Deirdre McCloskey, Vernon Smith), stimulus packages and government expenditures have no effects whatsoever on aggregate output, only lower taxes do. Indeed, it is believed by anti-Keynesians that Keynesian policies, along with the near zero interest rate policies which have been endorsed throughout, will prolong the crisis, as it would have done in Japan over the last fifteen years, notwithstanding the contrary evidence brought about by the likes of Richard Koo (2009).

\section{CONCLUSION}

It is difficult to predict whether the current financial crisis will indeed be a vector of change in macroeconomics.

Whether the popular movements that oppose stimulus programs and bigger government will have any effect on politicians and academic economists remains to be seen. What is the likely impact of the crisis on academia? Three scenarios can be described. In the first one, mainstream macroeconomics becomes ever more entrenched in its models and outrageous assumptions. At best the New consensus model will be slightly amended, while all other approaches will get dismissed. The second scenario, but in my view a less likely one, is that all other approaches, such as post-Keynesian economics, will benefit from more tolerance, even if they don't incorporate the crucial intertemporal utility maximizing representative agent with rational expectations, provided these other theories are formalized in some way.

Finally, a middle-of-the-road scenario is that orthodox dissent will get a much better hearing, while heterodox dissent, like post-Keynesian economics, will still 
have a hard time getting such a hearing within the profession. This is perhaps the most likely scenario. The financial crisis will probably generate a demand for orthodox dissenters within economics departments; indeed they are likely to be the biggest winners, especially those specializing in behavioural finance, as they will be sought after by government regulation agencies or such similar institutions.

However, I would argue that the standing of heterodox dissenters (including post-Keynesians) should improve in departments other than economics, in the social sciences in general and in political science in particular, and in departments such as public administration and public affairs, international affairs, social studies, industrial relations, real estate, and even in business schools. Members of these fields are more likely to look for alternative views, and they ought to find themselves in sympathy with the methodology of heterodox dissent.

Now what about the impact of the financial crisis on economics at large? I would suppose that in the short run, especially if unemployment rates keep rising, many more students will take economics in undergraduate programs, in the hope of finding out how the financial crisis erupted and why it did. This should help to reverse a long-run trend of disinterest for economics among graduate and undergraduate students. It is unlikely, however, that economics students will be provided with any satisfactory answer. As a result, in the medium run, there should be even less students than before in (orthodox) economics department, as students will become disenchanted with their chosen field.

Government employers are themselves already disillusioned with economics, as the financial crisis has demonstrated the futility of standard economic advice and theories. Economics departments may become like departments of philosophy, theology, or ancient studies. As Craufurd Goodwin (2000, p. 183) suspects, economics is already getting supplanted by many new neighbouring fields, the ones that I just said were likely to be in sympathy with heterodox dissent. So while life may still be difficult for heterodox Keynesians within the field of economics proper, heterodox Keynesians may benefit from the interest in heterodox views that the financial crisis is likely to generate in these expanding fields.

\section{REFERENCES}

AKERLOF, G.A. and R.J. SHILLER (2009) Animal Spirits, Princeton University Press.

BACKHOUSE, R.E. (2004) “A suggestion for clarifying the study of dissent in economics”, Journal of the History of Economic Thought, 26 (2), June, 261-271.

BUITER, W. (2009) “The unfortunate uselessness of most 'state of the art' academic monetary economics, Financial Times, 3 March, http://blogs.ft.com/maverecon/2009/03/the-unfortunate-uselessness-of-most-state-of-the-art-academic-monetary-economics/\#more-667

COLANDER, D. (ed.) (1996) Beyond Microfoundations; Post Walrasian Macroeconomics, University of Cambridge, Cambridge.

COLANDER, D, R.P.F HOLT and J.B. ROSSER (2004) "The changing face of mainstream economics”, Review of Political Economy, 16 (4), Octover, 485-500.

DAVIDSON, P. (2009) The Keynes Solution, Palgrave/Macmillan, London. 
DUTT, A. (2003) “On Post Walrasian economics, macroeconomic policy and heterodox economics", International Journal of Political Economy, 33 (2), Summer, 47-64.

FOX, J. (2009) The Myth of the Rational Market, HarperCollins, New York.

GALBRAITH, J.K. (1994-95) “John Maynard Nosferatu”, Journal of Post Keynesian Economics, 17 (2), Winter, 249-260.

GOODHART, C.A.E. (2009) "The continuing muddles of monetary theory: A steadfast refusal to face facts", Economica, 76 (s1), October, 821-830.

GOODWIN, C.D. (2000), “Comment: It's the homogeneity, stupid!”, Journal of the History of Economic Thought, 22 (2), 179-183.

HODGSON, G.M. (2009) "The great crash of 2008 and the reform of economics", Cambridge Journal of Economics, 33(), 1205-1221.

KALDOR, N. (1966) "Marginal productivity and the macro-economic theories of distribution: Comment on Samuelson and Modigliani”, Review of Economic Studies, 33, October, 309-319.

KING, J.E. (2009) "Heterodox macroeconomics: What, exactly, are we against?", in L.R. Wray and M. Forstater (eds), Keynes and Macroeconomics After 70 Years, Edward Elgar, Cheltenham.

KOO, Richard C. (2009) The Holy Grail of Macroeconomics: Lessons from Japan's Great Recession, John Wiley and Sons, Singapore.

KRUGMAN, P. (2009) “How did economists get it so wrong?”, New York Times, 6 September, http:// www.nytimes.com/2009/09/06/magazine/06Economic-t.html?_r=1\&em=\&pagewanted=print

LAVOIE, M. (1992) “A moeda em um programa de pesquisa comum para o pós-keynesianismo e o neo-ricardianismo", Revista de Economía Politica, 12 (3), julho-setembro, 107-129.

MANKIW, N.G. (2006) “The macroeconomist as scientist and engineer", Journal of Economic Perspectives, 20 (4), Fall, 29-46.

POSNER, R.A. (2009a) A Failure of Capitalism, Harvard University Press, Cambridge (Mass.).

POSNER, R.A. (2009b) "How I became a Keynesian”, The New Republic, 23 September.

ROGERS, C. (2009) "Why much 'state of the art' monetary theory was unable to anticipate the global financial crisis: A child's guide”, working paper, School of Economics, University of Adelaide.

STIGLITZ, J. E. and B. GREENWALD (2003) Towards a New Paradigm in Monetary Economics, Cambridge University Press, Cambridge.

WOODFORD, M. (2009) “Convergence in macroeconomics: Elements of the new synthesis”, American Economic Journal: Macroeconomics, 1 (1), 267-279.

WOODS, T.E. Jr (2009) Meltdown, Regnery Publishing, Washington. 